\title{
KYSYNNÄN HINTAJOUSTAVUUDEN MÄÄRITTÄMINEN JA KYSYNNÄN KAUSIVAIHTELU
}

\author{
PaAvo KaARlehto \\ Maatalouden taloudellinen tutkimuslaitos, Helsinki
}

Saapunut 27, 8. 1954

Eräs ekonometrisen tutkimusmenetelmän mielenkiintoisimmista ja käytännön kannalta toistaiseksi merkityksellisimmistä sovellutuksista on erilaisten tuotteiden kysynnän hintajoustavuuden määrittäminen. Niin yksinkertainen kuin joustavuuden matemaattinen esitys onkin (vrt. esim. 1, p. 140) ei tyydyttävien, käytännöstä saatuun aineistoon perustuvien laskelmien teko ole suinkaan helppoa. Vaikeuksia aiheuttaa ennen kaikkea hintajoustavuuden määrityksessä oleellinen staat. tisuuden vaatimus. Tarkasteltavan hyödykkeen kysyntää kuvaavan vakiomuotoisen funktion soveltaminen talouselämän dynaamisten riippuvuussuhteiden alaisiin monitahoisiin tapahtumasarjoihin on käytännössä aina jossain määrin epätarkka prosessi.

Staattisen kysyntäanalyysin perushypoteesin mukaan edellytetään riippuvainen muuttuja, kysytyn hyödykkeen määrä, ja riippumaton muuttuja, hyödykkeen hinta. Hyödykkeen hinnan muutoksien aiheuttajana tulee siten olla jonkin ulkopuolisen tekijän, kuten hallituksen hintapäätöksen tai säännöstelyvapaana aikana yleensä ko. hyödykkeen tarjonnan vaihtelun. Perushypoteesi sulkee siis hintojen ja kysyttyjen määrien molemminpuolisen vuorosuhteen välttämättä analyysin ulkopuolelle. Hypoteesin todistaminen, mikä luonnollisesti olisi tärkeätä ennen kysyntäfunktioiden määrittämistä, ei kuitenkaan ole varsin helppoa. Niinpä WoLD $(7$, p. 10$)$ toteaakin "The literature on demand analysis is not very explicit on this point, perhaps because the dependence of demand on price has been regarded as so obvious as not to require any comment, but nonetheless the question has certain aspects that require careful consideration». Todeten epätilastolliseen tarkasteluun turvautumisen ainoaksi mahdollisuudeksi WoLD esittää perushypoteesin todisteena ennen kaikkea, että kuluttajaa kaupassa kohtaa kiinteä hintataso. Kuluttajalle ei täten ole yleensä mahdollisuuksia hintaneuvotteluihin esim. siinä muodossa, että hän lupaisi ostaa enemmän mikäli hintaa alennetaan, mikä jo osoittaisi kaksipuolista riippuvuussuhdetta hintojen ja kysyttyjen määrien välillä. 
Epäilemättä tällainen tilanne päivittäisessä kaupankäynnissä varsinkin elintarvikkeiden kohdalla on varsin yleinen. Jos kuitenkin tarkastellaan kysymystä kokonaisuutena voidaan tässä suhteessa esittää eräitä huomautuksia. Mikäli myydyissä määrissä, menekissä, hinnanmuutoksista riippumatta esiintyy voimakkaita säännöllisiä vaihteluita voitaneen pitää todennäköisenä, että myyjät pyrkivät eliminoimaan tällaisia menekin muutoksia vastakkaisen vaikutuksen omaavalla hintapolitiikalla. Varsinkin jos tarkasteltavan hyödykkeen tuottajat esimerkiksi osuustoiminnallisten järjestöjen kautta esiintyvät markkinoilla, voi ehkäisevällä tai ennakoivalla hintapolitiikalla olla käytännössä merkitystä. Tällaisesta tapahtumakompleksista, jossa hinnan muutos ei olekaan primäärinen ja myydyn määrän muutos sekundäärinen ilmiö, tilastoihin viety numeroaineisto ei siten teoriassa täytä joustavuustutkimukselle asetettavaa yksipuolisen riippuvuussuhteen perusvaatimusta.

Näyttääkin siltä, että laskelmia tehtäessä usein kiinnitetään kaikki huomio ns. ceteris paribus ehdon täyttämiseen. Tällaisina muina tutkimuksen tulokseen vaikuttavina tekijöinä tarkastellaan sinänsä tärkeitä kysymyksiä kuten esim. läheisten substituuttien hinnan ja ostajien tulotason kehitystä sekä kulutustapojen pitkäaikaisia muutoksia. Näillä selvityksillä ei kuitenkaan voida aina taata tutkimusten tulosten pätevyyttä. Lähinnä kysynnän kausivaihteluilmiöstä johtuvat edellä mainitut menekin säännölliset muutokset saattavat aiheuttaa joustavuustutkimuksen suorittamiselle käytännössä jo tarkasteltujen seikkojen lisäksi myös muita vaikeuksia ja virhelähteitä. Kysynnän kausivaihtelu merkitsee näet aina tiettyä muutosta kysyntäolosuhteissa, mikä selvästi loukkaa kysyntäanalyysin staattista luonnetta.

Ajateltakoon esimerkiksi kysynnän hintajoustavuuden määritystä varten kerätyksi tilastoaineistoa tietyn hyödykkeen myyntimääristä ja hinnoista ja nämä arvot sijoitetuksi hinta-määrä koordinaatistoon kuviossa 1. Tällöin voidaan päätyä esim. tapaukseen, jossa käytettävissä vuoden ajalta on viisi havaintoparia hinnan muutoksista ja sen vaikutuksesta myytyihin määriin (havaintoparit a, b, c, d ja e).

Havaintoparien valinnassa on luonnollisesti vältetty erikoistapauksia, juhlapäiviä yms. Kysyntäkäyrän piirtäminen ja kysynnän hintajoustavuuden määrittäminen annettujen havaintojen perusteella tuntuisi tässä tilanteessa varsin helposti ratkaistavalta tehtävältä esim. matemaattisin menetelmin. Ennen laskelmien suoritusta on kuitenkin vielä selvitettävä, ovatko kysyntäolosuhteet tarkastellun kauden aikana pysyneet muuttumattomina, ja tällöin lähinnä se, mikä on aiheuttanut hinnan muutokset. Jos vaihtelun syynä on esim. hintaviranomaisten päätös tai kyseisen hyödykkeen tarjonnan muutos (tuotannon vaihteluista johtuva tarjontakäyrän siirtyminen), voidaan yleensä joustavuuden määritys oikeutetusti suorittaa saatujen havaintojen nojalla korjauksia suorittamatta. Kysyntä-tarjontatilannetta voitaisiin tällöin esittää kuvion 2 tapaan.

Useissa tapauksissa on käytännössä kuitenkin varsin vaikea selvittää onko hinnan vaihtelujen syynä ollut juuri tarjonnan muutos. Jos esim. havaintoparit a, b, c, d ja e olisi otettu maalis-, huhti-, tammi-, loka- ja marraskuulla voitaisiin 


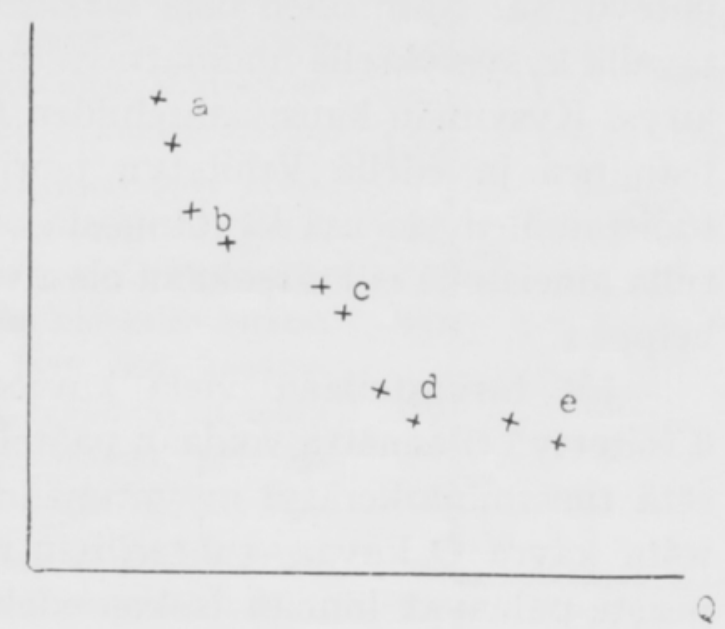

Kuvio 1. - Figure 1.

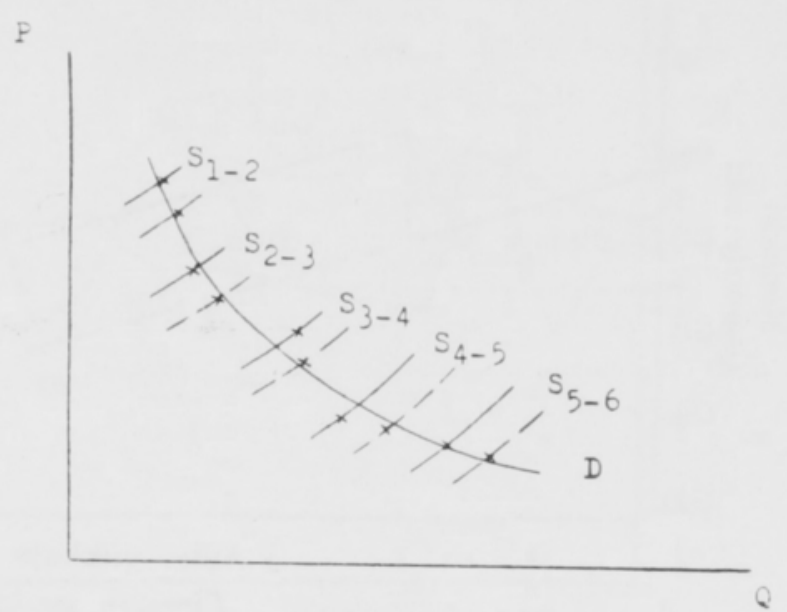

Kuvio 2. - Figure 2.

ajatella kevätkaudella menekin yleensä olevan pienemmän kuin syksyllä, mikäli hintataso on sama. Tällöin kysyntäolosuhteet eivät tutkimuskaudella olisi muuttumattomia, eikä siis staattisuuden vaatimusta voitaisi katsoa täytetyksi. Hinnanmuutokset saattaisivat tällaisessa tapauksessa olla kokeneiden myyjien ennakointia, kuten edellä jo on viitattu.

Jos nyt pyritään tarkemmin erittelemään miten tilastoihin kerätyt havainnot saattavat johtaa joustavuustutkimuksissa harhaan, lienee havainnollisinta jälleen turvautua graafiseen esitykseen. Tutkittavaksi voidaan ottaa esim. yksi havaintopari kevätkaudelta, jolloin menekillä edellytettiin olevan aleneva suunta.

Kuviossa 3 käyrä Q kuvaa hyödykkeen menekkiä aikayksikössä siten, että hinta kahden ensimmäisen viikon aikana on sama. Q-käyrää ei siis pidä sekoittaa tavanomaiseen kysyntäkäyrään, joka kuvaa määrätyissä olosuhteissa erilaisiin hintoihin kysyttyjä hyödykemääriä.

Tutkittavan ajanjakson kahdelta ensimmäiseltä viikolta on myytyjen määrien keskiarvoksi laskettu ON-yksikköä, havainto 1. Kolmannen viikon ensimmäisenä päivänä on hinta laskenut tietyllä arvolla ja tämä uusi hinta on pysynyt muuttumattomana seuraavat kaksi viikkoa, jolta havainto 2 on laskettu keskiarvona, vastaten määrää OM. Kerätyssä tilastossa esiintyy tietyn hinnanmuutoksen vaikutuksena menekkiin määrä MN. Nyt on varsin tärkeä havaita tilastossa esiintyvä virheellisyys. Vertailtaessa hinnanalennuksen johdosta tapahtunutta myydyn määrän muutosta, olisi havainto 1, jonka suhteen vertailu suoritetaan, saatava kuvaamaan menekkiä kolmannen ja neljännen viikon aikana olosuhteissa, joissa hinta ei olisikaan muuttunut. Kuviossa tämä on esitetty pisteviivalla, jonka perusteella voidaan havaita myydyn määrän muutoksen olleen KM, eli suuremman kuin mitä tilastolla välittömästi voitiin havaita. Luonnollisesti voitaisiin vastaavanlainen päättely suorittaa hinnan nousun vaikutuksista silloin kun kulutus on lisääntymässä.

Kirjoittajan käsityksen mukaan on todennäköistä, että useimpien hyödykkeiden kysynnässä tapahtuu määrättyä kausivaihtelua ja että hyödykkeen hinnan muutokset vapaassa markkinataloudessa usein tapahtuvat juuri näiden muutosten 


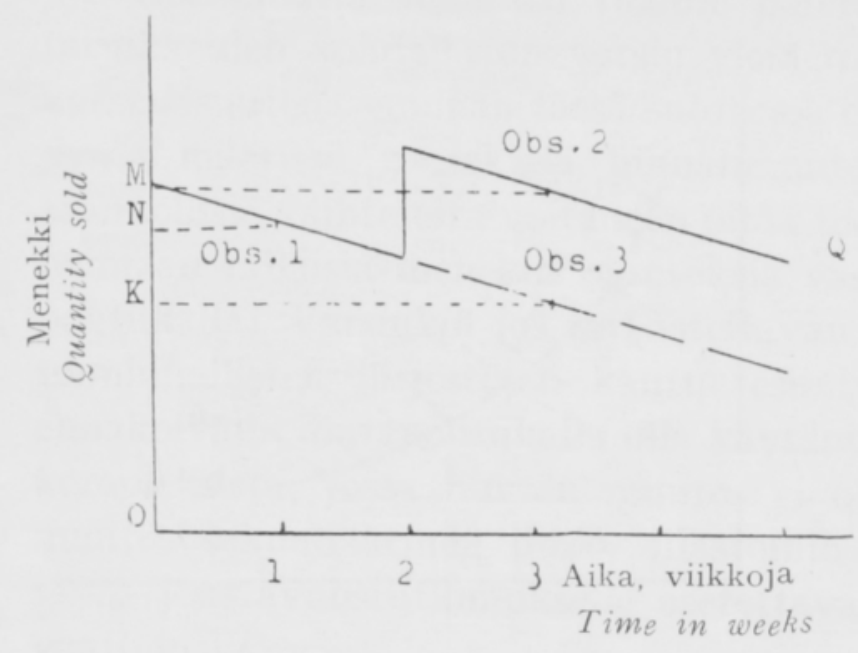

Kuvio 3. - Figure 3

yhteydessä. Näin ollen olisi tarkasteltavalla kysymyksellä huomattava merkitys. Kysynnän kausivaihteluiden toteaminen ja edellä kehitetyn teorian todistaminen yleensä käytännöstä otetulla aineistolla ei kuitenkaan ole aivan helppoa.

Jos tarkastellaan vielä kuviossa 3 esitettyä tilannetta voidaan päätellä, että tilastoihin kerätyt myyntimäärät, joita käyrä Q kuvaa, suhteellisen nopeasti palaavat hinnan laskua edeltäneelle tasolle. Kuviossa näin ajateltiin tapahtuvan n. 20 pv. hinnan muutoksen jälkeen. Tätä seikkaa voitaisiin ehkä käytännössäkin pitää eräänä viitteenä siitä, että hinnanmuutos on ollut kysynnän vaihtelun aiheuttama. On ehkä vielä syytä korostaa tässä yhteydessä, ettei kulutuksen alenemisen ennen hinnanmuutosta suinkaan tarvitse olla huomattavaa. Jos myyjä tietää kokemuksesta odottaa kulutuksen pienentymistä, hän saattaa ennakoida hinnan muutoksen sen kauden alkuun, jolloin kulutuksen odotetaan entisillä hinnoilla alkavan pienentyä. Täten ei hinnanmuutosta edeltäneestä kulutusmäärien kehityksestä voida varmuudella päätellä kysyntäolosuhteiden muuttumattomuutta.

Suoritetuissa joustavuustutkimuksissa on selitetty kulutuksen palaaminen hinnan muutosta edeltäneelle tasolle johtuvaksi hinnan muutoksen psykoloogisen vaikutuksen laimenemisesta (vrt. esim. 5, p 87). Niin uskottavalta kuin tämä selitys tuntuukin, on kuitenkin huomattava, ettei sen paikkansapitävyyttä ole tiettävästi todistettu vertailevilla kulutustutkimuksilla tai muilla keinoilla.

Mikäli hintajoustavuuden määrityksessä nyt halutaan vapautua kysynnän kausivaihteluiden aiheuttamasta virheellisyydestä, voitaisiin kysynnän luonnetta ajatella tutkittavan niin pitkien ajanjaksojen keskiarvoihin nojautuen, että kausivaihteluilmiö eliminoituisi. Kun kuitenkin tutkimuskauden pituus saattaa ceteris paribus ehdon täyttämisen kyseenalaiseksi, joudutaan joustavuuslaskelmissa varsin yleisesti käyttämään viikko- tai kuukausikeskiarvoja, jotka ovat kausivaihteluiden alaisia.

Esitetyn teoreettisen tarkastelun ohella lienee paikallaan selvitellä kysynnän kausivaihtelun merkitystä hintajoustavuuden määrityksessä käytettävissä olevaan tilastoaineistoon perustuvan esimerkin valossa. Maataloustuotteiden piirissä pysyttäessä antanee voin hinnan ja myyntimäärien regressiosuhteen analysointi ehkä parhainta selvitystä tässä suhteessa (vrt. 4, p. 103). Viime vuosina ovat voin hinnan muutokset tapahtuneet, yleensä lähinnä talouspoliittisista syistä johtuen, hallituksen päätösten perusteella, joten kysynnän kausivaihtelun merkitys hintaan vaikuttavana tekijänä on varmaankin ollut erittäin vähäinen. Sikäli kuin maassa olevien voivarastojen muutokset ovat olleet hintapäätöksiin vaikuttamassa, ei tätä väitettä kuitenkaan voida esittää täydellä varmuudella. Varastojen suuruuteen ovat näet 
Kuvio 4. Voin hinnan ja myytyjen määrien vaihtelujen suhteelliset arvot kuukausittain. Kuukausiarvojen tasoitus on suoritettu siten, että koko tutkimusperiodin indeksien summa on 2400. Eri kuukausien lukuihin on tehty tavanomainen päiväluvun mukainen korjaus.

Figure 4. Butter prices and quantities sold monthly indices.

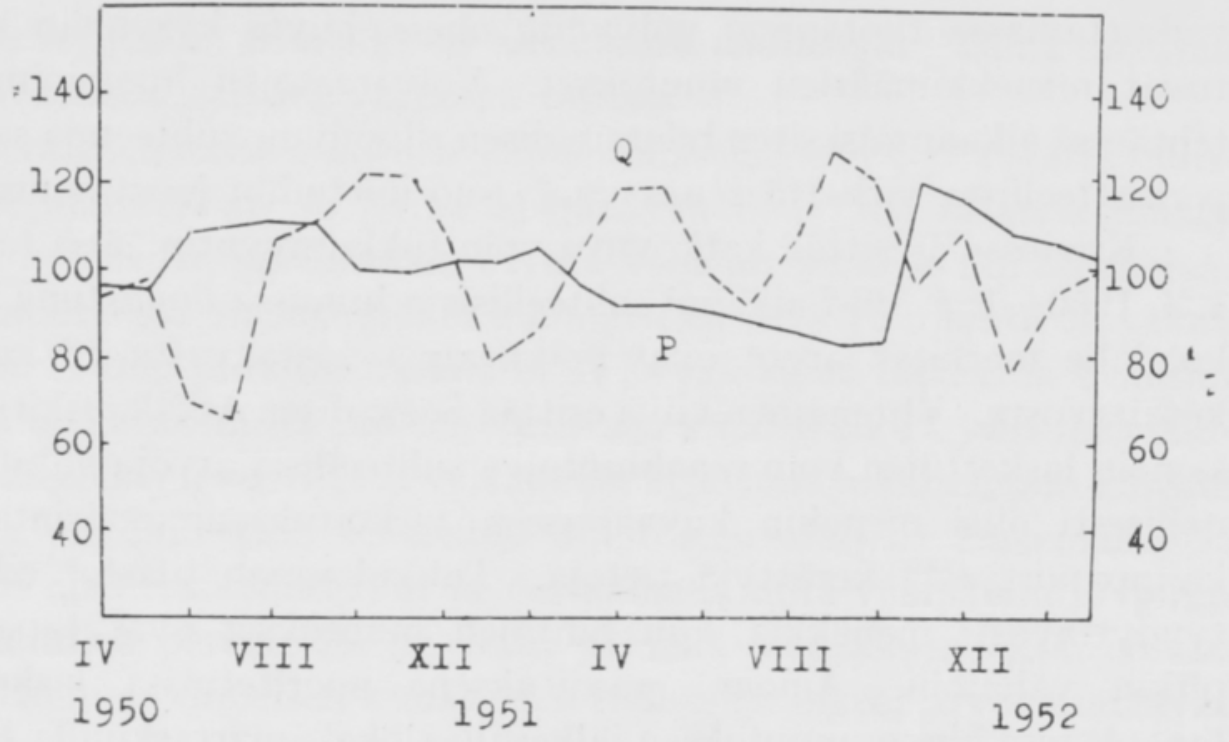

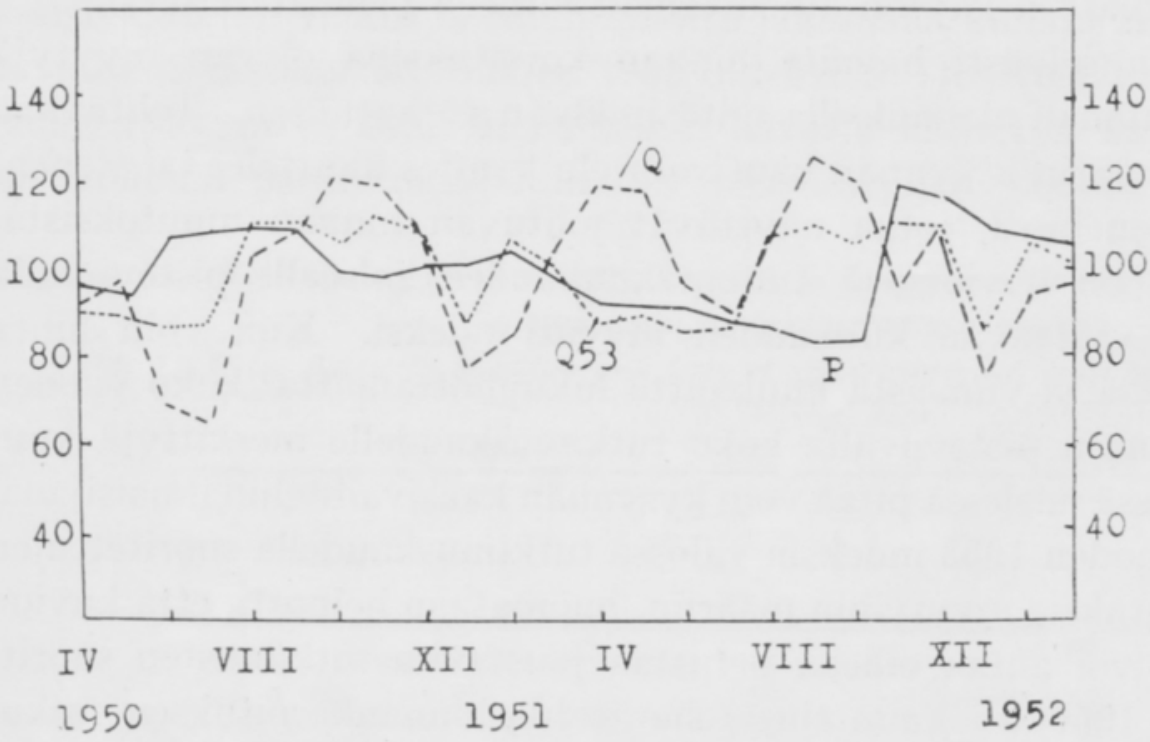

Kuvio 5. Voin hinnan ja myytyjen määrien vaihtelujen suhteelliset arvot verrattuna vuoden 1953 menekki-indeksiin kuukausittain.

Figure 5. Monthly indices of butter prices and quantities sold as compared with the corresponding quantity indices of 1953 .

Kuvio 6. Voin hintaja määräsarjat kysynnän kausivaihtelun eliminoinnin jälkeen.

Figure 6. Monthly indices of butter prices and quantities sold, with seasonal fluctuation eliminated.

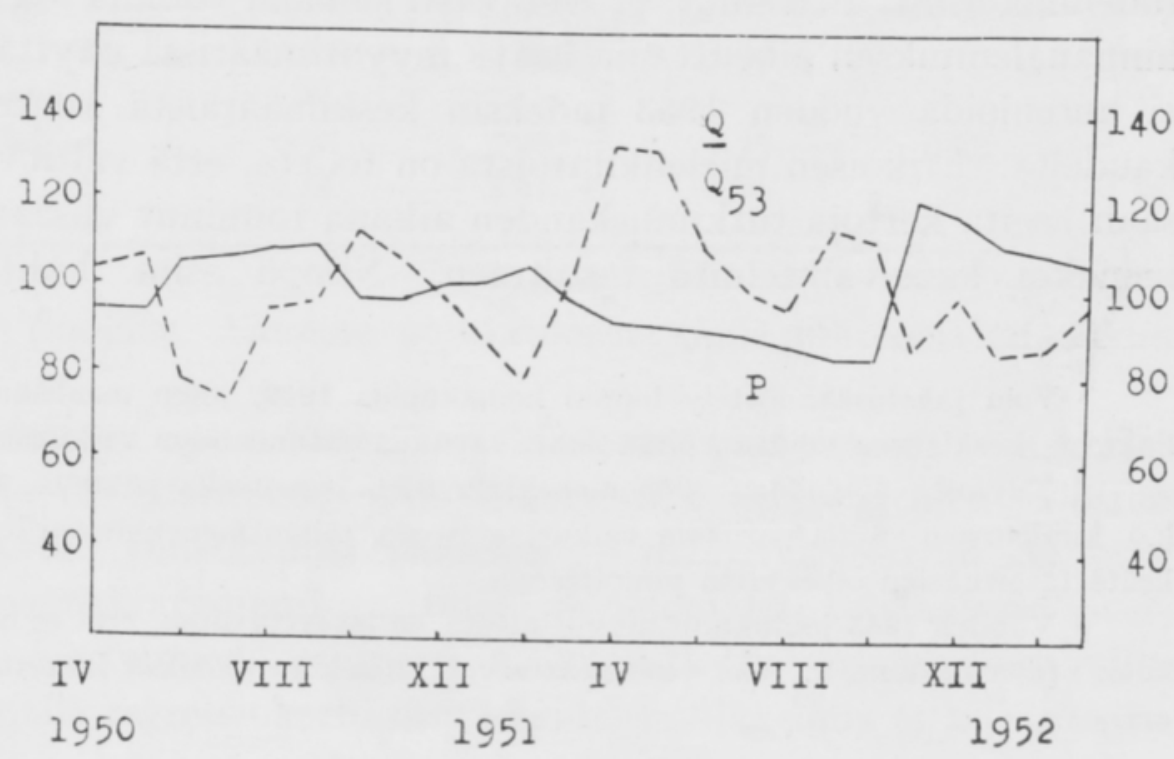


vaikuttamassa tuotannon volyymin ohessa myös kysynnän kausivaihtelusta johtuvat menekkimäärien muutokset. Voivarastojen huomioiminen hintapäätöksiä tehtäessä aikaansaisi siten bilateraalisen riippuvuussuhteen ja samalla jossain määrin periaatteellista virhettä seuraavassa suoritettuihin joustavuuslaskelmiin.

Kuviossa 4 esittää katkoviiva voin tukkumyyntimääriä tarkasteltavan kauden 1. 4. $1950-1.4 .1952$ aikana $^{1}$ suhteellisissa luvuissa ilmaistuna. Kunkin kuukauden kohdalle merkityt arvot ovat poikkeamia vastaavasta 12 kuukauden liukuvasta keskiarvosta. Yhtenäinen viiva esittää Sosiaalisen Aikakauskirjan (8) hintatilastosta samoin laskettujen voin reaalihintojen suhteellisia arvoja vähittäiskaupassa. Luonnollisesti olisi menekin kuvaamiseen tarkoituksenmukaisinta käyttää vähittäiskauppaportaasta kerättyjä tietoja. Tukkukaupan tilastot edustanevat kuitenkin tyydyttävästi menekkiä, kun hintojen muutokset ovat tapahtuneet suhteellisen pitkin väliajoin. Ainoana tasoituksena suoritetuissa laskelmissa on kahdessa tapauksessa hinnanmuutoksen jälkeisille (loka-marraskuulla 1950 ja huhti-toukokuulla 1951) kahdelle kuukaudelle katsottu tarpeelliseksi laskea menekkilukujen keskiarvo tukkukauppatilaston käytön aiheuttaman virheen pienentämiseksi. ${ }^{2}$

Kuviosta 4 voidaan selvästi havaita hinnan koroituksilla olevan myytyjä määriä pienentävän ja hinnan alennuksilla niitä lisäävän vaikutuksen. Tehtävänä on nyt selvittää, missä määrin kysynnän kausivaihtelu kenties liioittelee tai pienentää niitä vaihteluita menekissä, jotka näyttävät johtuvan hinnan muutoksista. Tätä tarkoitusta varten on kuviossa 5 kunkin kuukauden kohdalle pisteviivalla merkitty vuoden 1953 vastaavan kuukauden myynti-indeksi. Kun voin hinta vuonna 1952 loppupuolella ja viimeistä kuukautta lukuunottamatta ${ }^{3}$ koko vuoden 1953 oli tasainen, voitaneen pisteviivalla koko tutkimuskaudelle merkittyjä kuukausi-indeksejä määrätyssä mielessä pitää voin kysynnän kausivaihtelun ilmaisijana.

Jos tarkastellaan vuoden 1953 indeksin valossa tutkimuskaudella suoritettujen hinnan muutosten vaikutuksia myytyihin määriin, huomataan helposti, että kuvion 4 mukaiset arvot eivät voi antaa oikeaa perustaa joustavuustutkimusten suorittamiseksi. Niinpä esim. 1950 kesäkuun alusta suoritetun hinnankoroituksen vaikutus tulee liioitellusti esiin, koska menekki olisi vakaan hintatasonkin vallitessa todennäköisesti alentunut. Vastaavasti samana vuonna lokakuun alussa suoritetun hinnanalennuksen aiheuttama lisäys myyntimäärissä näyttää liian suurelta, mikäli ei huomioida vuoden 1953 indeksin keskimääräistä korkeampia arvoja samalta kaudelta. Erikoisen mielenkiintoista on todeta, että valtiovalta on hintapolitiikassaan useita kertoja tutkimuskauden aikana toiminut viisaan kauppamiehen tavoin menekin kausivaihteluita tasoittaen. Niinpä esim. huhtikuinen hinnanalennus

1 Voin jakelusäännöstely loppui heinäkuussa 1949 , joten maaliskuun 1950 kohdalle laskettua liukuvaa keskiarvoa voidaan pitää suht, vapaana säännöstelyn vaikutuksista.

2 Kuviosta 5 voidaan 1953 menekkilukujen perusteella päätellä, että kysynnän kausivaihtelu k.o. kuukausien välillä parittain vaikuttaa varsin vähän menekkimääriin, mikä luonnollisesti on tärkeätä tasoituksien oikeutusta punnittaessa.

3 Vuoden 1953 joulukuun myyntimäärä on laskettu siten, että se on samassa suhteessa marraskuun myyntiin kuin v. 1952 vastaavat arvot. Kuukausi-indeksit laskettu vertaamalla vuoden keskiarvoon. 
v. 1951 sattuu kaudelle, jolloin menekki on alenevassa suunnassa. Tämä on siten täysin kuvion 3 teoreettista esitystä vastaava tapaus.

Kysynnän kausivaihtelun vaikutuksen eliminoimiseksi myytyjä määriä edustavista luvuista olisi mahdollista suorittaa korjaus vuoden 1953 tasaista hintaa edustavalla menekki-indeksillä, jos indeksin arvoja voidaan pitää kyllin tarkkoina. Luotettavuutta arvosteltaessa on ensinnäkin huomattava, että voin hinta oli vakaa yli puolitoista vuotta. Täten on kulutuksella ollut hyvää aikaa hakeutua tasaisiin uomiinsa viimeisen hinnanmuutoksen jälkeen ennen sen kauden alkua, jolta menekkiindeksi on laskettu. Lisäksi on suoritettu vertailevia laskelmia aikaisempiin kausiin nähden, jolloin hinta on ollut vain vähäisten muutosten alaisena laskemalla eri kuukausina myytyjen määrien suhdeluvut ja vertaamalla niitä vastaaviin arvoihin vuodelta 1953. Vertailujen perusteella on voitu päätellä menekki-indeksin olevan melko luotettavan. Kolmen viimeisen kuukauden indeksien oikeat arvot saattavat kuitenkin olla esitettyjä vielä hieman korkeampia.

Kuviossa 6 esitetään tutkimuskaudelta lasketut menekkimäärien arvot, joista kausivaihtelun vaikutus on eliminoitu jakamalla kunkin kuukauden myyntiä osoittava luku vastaavalla vuoden 1953 indeksillä. Jos verrataan kuviota 4 ja 6 keskenään, voidaan jo silmävaraisestikin havaita käytetyn kausivaihteluiden tasoitusmenetelmän parantaneen hinta ja määräsarjojen säännöllistä esiintymistä keski-

Taulukko 1. Voin hintajoustavuuden lukuarvot ja niiden merkitsevyys; a) kysynnän kausivaihtelu eliminoitu, b) korjaamaton aineisto.

Table 1. Price elasticity of butter and tests of significance; a) seasonnal fluctuation eliminated, b) original data.

\begin{tabular}{|c|c|c|c|c|c|}
\hline & & $\begin{array}{c}1 \\
-\mathrm{e}\end{array}$ & $\begin{array}{l}2 \\
\mathrm{~F}\end{array}$ & $\begin{array}{l}3 \\
\mathrm{~s}_{b}\end{array}$ & $t_{e_{a-} e_{b}}^{4}$ \\
\hline 1. $4.50-1.4 .52$ & $\begin{array}{l}\mathrm{a} . \\
\mathrm{b}\end{array}$ & $\begin{array}{l}0.94 \\
0.77\end{array}$ & $\begin{array}{l}15.00 * * * \\
4.98\end{array}$ & $\begin{array}{l}0.24 \\
0.35\end{array}$ & 0.40 \\
\hline 1. $4.50-1.3 .51$ & $\begin{array}{l}\text { a. } \\
\text { b. }\end{array}$ & $\begin{array}{l}1.76 \\
1.32\end{array}$ & $\begin{array}{l}5.99 * \\
1.01\end{array}$ & $\begin{array}{l}0.72 \\
1.32\end{array}$ & 0.36 \\
\hline $1.3 .51-1.4 .52$ & a. & $\begin{array}{l}0.75 \\
0.59\end{array}$ & $\begin{array}{l}7.59^{*} \\
3.91\end{array}$ & $\begin{array}{l}0.27 \\
0.30\end{array}$ & 0.35 \\
\hline
\end{tabular}

määräisen arvon 100 eri puolilla. Ainoana poikkeuksena tässä suhteessa on elokuu 1951.

Varsin mielenkiintoista on nyt määrittää esillä olevasta aineistosta voin hintajoustavuuden lukuarvoja eri tilanteissa sekä erikoisesti tutkia saatujen tulosten tilastollista merkitsevyyttä. Joustavuuskertoimien (e) määrityksessä on käytetty suhteellisten hinta- ja menekkiarvojen logaritmeja tavanomaisia työkaavoja soveltaen (vrt. esim. 6, p. 73). Kertoimien merkitsevyyttä on tutkittu varianssianalyysilla (F-testi) sekä määrittämällä regressiokertoimen standardipoikkeama $\left(\mathrm{s}_{\mathrm{b}}\right)$. Saatujen 
tulosten eroavaisuuksien merkitsevyyttä on tutkittu t-testiä käyttäen. Kun alan oppikirjoista (esim. 2 ja 3) saa tarkan selvyyden ko. tilastomenetelmien kaavoista ja niiden sovellutusmahdollisuuksista, on esillä olevassa tutkimuksessa tähän puoleen puuttumista pidetty tarpeettomana. Voin hintajoustavuuden määritys on suoritettu erikseen korjaamattomasta ja vuoden 1953 menekkilukujen perusteella tasoitetusta aineistosta 1) koko tutkimuskaudelle ja 2) kauden alku- ja loppuosalle. Tulokset esitetään taulukossa 1.

Kysynnän hintajoustavuuden lukuarvot taulukon ensimmäisessä sarakkeessa osoittavat, että korjausmenetelmää käyttäen laskettu joustavuus tutkimuskaudella olisi hieman suurempi kuin alkuperäisen aineiston perusteella määritetty. Tämä merkitsisi sitä, että keskimäärin on hallituksen hintapolitiikalla ollut lievä menekin kausivaihtelua tasoittava vaikutus. Sarakkeesta 4, jossa on t-testin avulla tutkittu joustavuusarvojen eroja, voidaan kuitenkin havaita, että kyseessäolevan eron merkitsevyys on vähäinen. Tämä tuntuu ymmärrettävältä kun otetaan huomioon, että kunkin hinnan voimassaoloaika on ollut varsin pitkä. Näinollen kysynnässä on ehtinyt tapahtua muutoksia. Esim. 1.6.50 suoritettu hinnankoroitus on sattunut kaudelle, jolloin menekki on alenemassa ja vuoden keskimäärää pienempi. Tässä tapauksessa näyttäisi siis joustavuuskerroin korjaamattoman aineiston perusteella laskien tulevan liian suureksi. Saman hintatason vielä vallitessa kysyntäolosuhteet kuitenkin muuttuvat 1.8. niin, että korjaamaton aineisto antaisi liian alhaisen joustavuusarvon. Täten on selitettävissä joustavuuskertoimien vähäinen eroavaisuus taulukon 1 , a. ja b. kohdissa.

Niiden tekijöiden tarkasteluun, jotka ovat vaikuttamassa nimenomaan voin hintajoustavuuden lukuarvojen vaihteluun, ei kysymykseen liittyvästä mielenkiinnosta huolimatta ole paikallaan tässä yhteydessä ryhtyä. Esillä olevan tutkimuksen kannalta tärkeimpänä kysymyksenä on sensijaan erikoisesti selvitettävä suoritetun kysynnän kausivaihtelun eliminoinnin vaikutusta joustavuuslaskelmien luotettavuuteen. Tässä mielessä suoritetut määritykset antavat kehitetyn menetelmän käyttökelpoisuudesta varsin positiivisen kuvan. Tutkimuskauden keskimääräistä voin hintajoustavuutta 0.94 voidaan pitää varsin luotettavana. Erikoisesti on syytä panna merkille (vrt. taulukko 1, 2 ja 3 sarake), että poikkeuksetta kaikissa lasketuissa tapauksissa sekä F-testi että regressiokertoimen standardipoikkeama osoittavat käytetyn kausivaihtelun eliminointimenetelmän oleellisesti parantaneen joustavuuslaskelmien luotettavuutta.

KIRJALLISUUTTA

(1) Boulding, Kenneth E. 1948. Economic Analysis. New York.

(2) Ferber, Robert 1949. Statistical Techniques in Market Research. New York, Toronto, London.

(3) Goulden, C. H. 1949. Methods of Statistical Analysis. New York.

(4) Haikala, Eıno. 1952. Staattisesta kysynnästä. Kansantaloudellinen Aikakauskirja 28 p. 102 - 112.

(5) Korvisto, Esko. 1953. Tutkimuksia Suomen kulutusmaitomarkkinoista erikoisesti kulutus maidon hinnanmuodostuksen kannalta katsottuna. Maataloustieteellisen Seuran julkaisuja 82, Helsinki. 
(6) Pinkala, K. U. 1941. Suomen kananmunahintojen muodostumisesta maailmansodan jälkeen. Ibid. 46.

(7) Wold, Herman. 1952. Demand Analysis. Stockholm, New York.

(8) Sosiaalinen Aikakauskirja. Vuosikerrat 43-48.

\title{
S U M M A R Y :
}

\author{
SEASONAL FLUCTUATION OF DEMAND AND THE CALCUI.ATION OF PRICE \\ ELASTICITY FROM MARKET STATISTICS
}

PaAvo KaARLEHTo

\section{The Research Institute of Agricultural Economics, Helsinki}

Quite frequently the empirical demand analysis has to be based on time-series data on prices and quantities sold. However, the seasonal fluctuation of demand may cause some systematic errors in the demand function derived from this type of data. In the first place there is the question of whether it is correct to regard the butter demand as causally dependent on the butter price, or is it necessary to propose some bilateral interdependence between prices ans quantities sold. In the literature on demand analysis unilateral dependence has generally been regarded as axiomatic. This approach is based mainly on the fact that the consumer is confronted with fixed prices at the store, bargaining being practically absent (7). Knowing from previous experience the effects of seasonal fluctuation of demand sellers at a given market might tend to counteract this fluctuation by changing prices. Under price control this might affect the decisions of the responsible authorities, also. Thus the question of dependence requires careful consideration in each case studied.

The changing demand conditions might cause errors in a more technical sense, also. E.g. if the effect of a change in price is studied during a period of decreasing demand, market statistics might be misleading in the way illustrated in figure 3. The curve $Q$ refers to the quantities sold as given by market statistics. During the two tirst weeks an average quantity of ON has been sold. After a certain decrease in price, in the beginning of third week an increase in sales takes place so that during the third and fourth week averagely OM has been sold. The effect of the price change now seems to be NM. This, of course, is incorrect, since the basis for the comparison should be the quantity OK to which the sales would have decreased without the change in price. Consequently, the real effect of the price change is KM. The numerical value for the observation 3 in the diagram cannot be obtained from ordinary market statistics, however.

Under normal conditions it is difficult to study the problems outlined above. During the last few years the conditions on the butter market in Finland offer some interesting data from this point of view. Butter has been under price control for many years, whereas the demand for each prevailing price has been well satisfied. After a period of violent changes during 1950 and 1951 the price of butter has been stable during the latter part of 1952 and all through 1953. The sales of butter during the stable price period now offer valuable assistance for the calculation of the price elasticity for the years $1950-51$. The fluctuation indices (deviations from 12-month average) of butter prices and quantities sold are presented in figures 4 and 5. The Q53 curve represents the sales-index of the same type under a stable price. It is readily seen that if this seasonal fluctuation, which is represented by the 1953 salesindex, were disregarded, the regression calculation would be less significant. In figure 6 the seasonal fluctuation has been eliminated by dividing the indices of quantities sold for each month by the corresponding indices for 1953. The elasticity coefficients calculated from the corrected as well as from the original data are presented in table 1. The tests of significance argue very clearly in favour of the method of correction used. 